preenchimento do defeito pelo calo, direcionando os sistemas haversianos para a consolidação primária e minimizando os danos às estruturas adjacentes. Sua obtenção envolve a restauração do comprimento original do osso, alinhamento axial e orientação rotacional. Forças compressivas, rotacionais, de flexão e de cisalhamento devem ser consideradas quando se estabiliza uma fratura, assim como mínimo trauma aos tecidos moles e ao suporte vascular e muscular do osso. Freqüentemente a injúria ao tecido mole associada a uma fratura é mais provável de resultar na perda da função e consolidação retardada que a fratura por si só. Pássaros são particularmente propensos a desenvolver anquilose, atrofia muscular, contratura de tendão e envolvimento de tendões e ligamentos dentro do calo ósseo associados ao tratamento da fratura com imobilização externa, acompanhado de mau alinhamento da mesma. Pinos IM para fixação interna são familiares a maioria dos veterinários, relativamente econômicos, requerem pequena exposição cirúrgica, permitem alinhamento axial e contrabalanceiam as forças de flexão, porém não contraagem com as forças de rotação e de cisalhamento. Afirma-se que o peso dos pinos IM afeta o vôo, que sua proximidade à articulação apresenta tendência para causar fibrose periarticular e anquilose, que podem ainda causar injúria à vascultaura, tendão ou ligamento e significante alteração no padrão de crescimento ósseo, resultando em disfunção parcial do membro, sendo indicada a sua remoção cirúrgica o mais breve possível. Relatamos o uso de pino IM na reparação de fratura em um úmero, um fêmur e um tibiotarso de 3 papagaios e em dois tibiotarso de 2 araras operados no Serviço de Cirurgia de Pequenos Animais do HOVET-FMVZ/USP. Nos 5 casos houve evolução favorável com formação de calo ósseo, retorno à função normal e ausência de qualquer complicação às articulações, tendões ou ligamentos, apesar de não removidos os pinos posteriormente, mostrando tratar-se de técnica segura, adequada, e desde que cuidadosamente realizada pode ser indicada como método de fixação interna para fraturas em ossos longos dos pássaros.

\title{
22 - Alterações clínicas da Síndrome de Emagrecimento Progressivo de Sagüis mantidos em cativeiro
}

1- Departamento de Patologia da Faculdade de Medicina Veterinária e Zootecnia da Universidade de São Paulo-SP

2- Departamento de Patologia da Faculdade de Medicina da Universidade de São Paulo, São Paulo-SP

$\mathrm{Na}$ rotina de clínica de pequenos animais é crescente o número de atendimentos a animais selvagens mantidos como pets. Neste contexto, é importante o conhecimento de afecçòes especificas de algumas espécies mantidas em cativeiro por proprietários particulares, dentre elas os sagüis. A Síndrome de Emagrecimento Progressivo (SEP) é uma das principais causas de morbidade e mortalidade de sagüis mantidos em cativeiro de diversas coleções no mundo, incluindo no Brasil. Esta enfermidade, apesar do tratamento instituído, apresenta evolução longa e, freqüentemente, fatal. Mesmo com a elevada casuística apontada na literatura, a etiologia desta síndrome ainda não está estabelecida. Assim, o diagnóstico definitivo desta patologia é, muitas vezes, dificil, pois os sintomas são progressivos, inespecíficos e podem confundir o clínico. O presente trabalho visa a caracterizar qualitativamente as principais alterações clínicas observadas em sagüis com SEP. Foram examinados clinicamente 50 sagüis, de ambos os sexos, adultos e jovens, mantidos em cativeiro no Criadouro Mucky, Jundiai - SP, que apresentavam alterações clínicas sugestivas de SEP, no período de janeiro de 2000 a outubro de 2001. O exame clínico se constituiu da avaliação da temperatura interna, da condição corpórea (peso e distribuição da musculatura), das mucosas aparentes, do turgor cutâneo, da auscultação cardio-pulmonar, da palpação abdominal, da locomoção e dos reflexos proprioceptivos. Os exames foram realizados duas vezes por semana até o óbito do animal. Todos os animais foram medicados de forma semelhante, com antibióticos, 
antiparasitários, reposição hidroeletrolítica, vitaminas, aminoácidos e minerais. Os sagüis foram selecionados considerando os seguintes critérios: nascidos em cativeiro ou mantidos no criatório por mais de seis meses, que apresentassem peso ou crescimento abaixo do esperado; com mucosas pálidas sem causa determinada; apresentando diarréia ou fezes pastosas e adultos acasalados há mais de um ano e que não apresentaram gestação a termo. De forma qualitativa e geral, os sagüis que foram acompanhados eram adultos jovens e apresentaram alterações digestivas, hematológicas, genitourinárias, neuro-musculares, reprodutivas e cutâneas. Dentre as alteraçòes clínicas observadas inicialmente, o emagrecimento progressivo, distensão abdominal devido a dilataçào de alças intestinais, fezes pastosas volumosas, diarréia pastosa ou aquosa e anemia se destacaram como as mais freqüentes. Progressivamente, os sagüis apresentaram perda de massa muscular, perda da propriocepção dos membros, ataxia, diarréia intermitente e anemia. Os casos terminais se caracterizaram por caquexia, disfagia, diarréia não responsiva à terapia, decúbito lateral ou esternal, paralisia dos membros, anemia, proteinemia, candidiase e sepsis. A história clínica e o exame físico de sagüis, que apresentam emagrecimento, anemia, diarréia e paralisia, possibilitam diferenciar a SEP de patologias como traumatismos, parasitoses, desnutriçào protêica-calórica do filhote, diarréias infecciosas bacterianas e intolerância à lactose. Assim, as alterações descritas permitem caracterizar a síndrome como uma enfermidade progressiva e caquetizante, cujos sintomas digestivos se sobressaem e correspondem clinicamente a distúrbios crônicos, como insuficiência pancreática crônica, síndrome de má-absorçào e desnutrição protêico-calórica crônica. Agradecimentos: os autores agradecem a Lívia Botár, coordenadora do Projeto Mucky, e a todos os funcionários do criatório.

Financiamento: FAPESP, processo No 00/04412-1

\section{3 - Uso de Propofol intracelomatico em tigres do mississipi (Trachemys scripta elegans)}

Mouriño, J.M.P.'; Vasconcelos, A.S.'

\section{1- Médico Veterinário Autônomo}

Nos últimos anos o atendimento clínico, médico e cirúrgico, de animais silvestres e exóticos tem aumentado de forma sensivel em vários estabelecimentos veterinários, que até pouco tempo atrás, eram exclusivos para cães e gatos. $\mathrm{A}$ utilizaçào de várias destas espécies, como animais de estimação, exige do médico veterinário um novo tipo de abordagem e responsabilidade para com o paciente. No campo da anestesiologia, as informações atualmente disponíveis são limitadas no que se refere à diferenciação de espécies e utilização de novos protocolos. Dentre as várias classes, os répteis, em especial os quelônios, tiveram dedicado para si pouco estudo, por isso, o cuidado destes fica defasado em alguns aspectos, o que nào é justificado pela sua demanda no mercado. Estes animais, que possuem baixa taxa metabólica, necessitam de alguns cuidados diferenciados, já que os fármacos utilizados tardam a ser metabolizados e excretados. Por este motivo, a anestesia injetável está associada com recuperaçào anestésica lenta. O propofol é um agente anestésico hipnótico de ação ultra curta, sendo o fármaco de escolha para induçào anestésica em quelônios. Devido às dificuldades encontradas em realizar a sua aplicação intravenosa, quais sejam: características anatômicas como a pele espessa; posicionamento inadequado pelo fato destes animais, espantosamente fortes, protegerem-se dentro de suas carapaças; o presente trabalho tem por objetivo encontrar uma alternativa simples e eficaz. O estudo foi realizado com quatro tartarugas (Trachemys scripta elegans), onde cada animal foi submetido à aplicação de propofol, por via intracelomática, em dosagens que variaram entre $10 \mathrm{e} 90 \mathrm{mg} / \mathrm{kg}$. Foi constatado que, nas doses mais baixas (similares às utilizadas em mamíferos), estes animais praticamente não demonstravam sinais de induçào anestésica. Contudo, quando as doses utilizadas eram bastante altas, notou-se adequado relaxamento muscular, diminuição da interação animal-ambiente e esperada depressão das funçōes vitais; compativeis com indução anestésica. A via intracelomática foi utilizada por ser de fácil acesso. Em quelônios com maior peso corporal esta se torna menos viável, pois as altas doses necessárias 